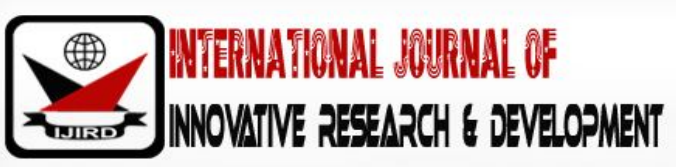

ISSN 2278 - 0211 (Online)

\section{Corrosive Politics and Dislocated Development: The Nigeria Scenario}

\author{
Ohiorenuan Ehikioya Charles \\ Assistant Lecturer, Department of Political Science, University of Benin, Nigeria \\ Akahomheh Collins \\ Assistant Lecturer, Department of Public Administration, Ambrose Alli University, Nigeria
}

\begin{abstract}
:
The Nigerian project has been a caricature of true development that is sustainable, it has not met the need of the present generation not to talk of meeting the needs of future generations. The researcher employed the use of secondary or historical and observation method to unravel the cause of this problematic in Nigeria's quest for the good life, it was discovered that the exit of the colonial masters, which many developments expert thought that it will bring genuine development, afterall did not come to fruition. This is due to individualistic and primordial ideology, that has no nationalist cleavage and that informed the corrosive politics that has not only dissembled the sustainable base of the economy, it has also weakened the institutions that would have fully utilized and transformed this vast resource to a meaningful whole to the benefit of the generality of Nigerians. There is a dislocation between agriculture and industries between the rural centres and urban centres, human resource capital and efficient bureaucracy, natural resource capital and effective utilization between consumption and production. However, if the politics of development can be adopted by the politicians and authoritative decision makers, Nigerian can still get it right. Further suggestions were given for the way forward.
\end{abstract}

Keywords: Politics, development, institution, ideology, values

\section{Introduction}

At independence in 1960, between 11:58pm of 30th September and 12:00am of October 1st when the union Jack (British Flag) was removed and the green white green flag of Nigeria was hoisted, Nigerians celebrated the dawn of a need era; the era of self-rule, extrication from colonial imperialism that manifested in economic exploitation and dehumanization of the people by the colonial masters.

There was shouts of hallelujah by the Christians, the Muslims shouted Allah Arkuba, there was shouts of happiness everywhere with high hopes that at last Nigerians can determine their future with the emergence of indigenous politicians and leaders. But events of the past 57 years have shown that we are worse off according to available economic and political indices of development.

Nigeria is an enigmatic case in sub-Saharan Africa in many ways, this important country of more than 170 million people has long possessed a high potential for developing into a regional and global super power with national wealth. Nigeria boasts abundant natural resources (especially light sweet crude oil, a vigorous civil society, highly educated elites and an enduring commitment to freedom, pluralism and enterprise among its people. At the same time, the country has been plagued since independence from Britain on October 1, 1960 by poor leadership and social structure that does not support unity of purpose (Sodaro, 2008:773).

Nigeria provides important insights into the political economy of underdevelopment. At independence in 1960, Nigeria was stronger economically than its South East Asian counterparts Indonesia and Malaysia. Independent Nigeria appeared poised for growth, within a wealth of natural resources, a large population, and the presence of highly entrepreneurial groups in many regions of the country. Today, Nigeria is among the poorest countries in the world in terms of per capita income, while many of its Asian counterparts have joined the ranks of the newly industrializing countries. One critical lesson Nigeria teaches is that a rich endowment of resources is not enough to ensure economic development. In fact, it may encourage rent - seeking behaviour that undermines more productive activities. Sound political and institutional development must come first (Kesselman, Kriegar, and Joseph, 2010:409).

\section{Conceptual/ Theoretical Analysis}

David, Easton defines politics as the authoritative allocation of values (wealth, worth or utilities (see Dahl and Stinebrickner 2003) Lasswell defines politics as who gets what, when and how? (Otoghile, 2009). The determination of ends, the choice of means, the balance of social forces, are the stuff of politics (Chapman, 1959:275) in (Adamolekun, 
community that humans can live the good life. From this view point, then, politics is an ethical activity concerned with creating a just society; it is what Aristotle called the master science (Heywood, 2007:8).

Development should be thought of not only in terms of income and consumption, but also in terms of people's health, education, housing conditions, security, civil rights and so on. Seen in this, development is clearly a normative concept that is, it involves values, goals and standards that make it possible to compare a particular situation against a preferred one (Knox, Agnew and McCarthy, 2008:23).

The Websters II college dictionary defines corrosive as a substance capable of causing corrosion and it is gotten from the 'noun' corrode and it means to gnaw away, to dissolve or eat away gradually especially by chemical action, to injure insidiously to deteriorate. Corrosive politics is politics that is guided by self-interest and not national interest, it is more of politics of the belly and the dominant interest of a few elite to the detriment of a larger majority.

Corrosive politics disintegrates a political system, it tears apart, it is politics of waste and misappropriation, it wastes resources, it leads to a state of disequilibrium in the economics of management and development. To dislocate means to displace from the normal position, to disorder or disrupt, dislocated development is a dislocation from the forces of development that is holistic, that ensures balance, dislocated development is a delinking of the base of societal development, the delinking of rural areas from the urban centres, it is the disarticulation in the national economy.

\subsection{Constructivism}

Constructivism is characterized by an emphasis on the importance of normative as well as material structures, on the role of identity in shaping political action and on the mutually constitutive relationship between agents and structures. Unit-level constructivism is the inverse of systemic constructivism, instead of focusing on the external, international domain, unit-level constructivists concentrate on the relationship between domestic social and legal norms and the identities and interests of states (Reus-mit, 2005:188).

Constructivists argue that understanding how non-material structures condition actors; identities is important because identities inform interests and in turn, actions, constructivists contend that agents and structures are mutually constituted. Normative and ideational structures may well condition the identities and interest of actors, but those structures would not exist if it were not for the knowledgeable practices of those actors (Reus-mit 2005:197; Wendts, 1992:406). Emphasis on the supervening power of structures and the predilection of many constructivists to study how norms shape behaviour suggest that constructivists are structuralists, just like their neorealist and Marxist counterparts and it is through reciprocal interaction that we create and instantiate the relatively enduring social structures in terms of which we define our identities and interests.

Normative and ideational structures are seen as shaping actors' identities and interest, through three mechanisms: imagination, communication and constraints. With regard to the first of these, constructivists are then nonmaterial structures is fleet what actors see as the realm of possibility: how they think they should act, what the perceived limitations on their actions are and what strategies they can imagine, left alone entertain, to achieve their objective. Institutionalised norms and ideas thus condition what actors consider necessary and possible, in both practical and ethical terms (Reus-mit, 2005:198).

The structural-functional approach is an off-shoot or derivative of the systems analysis and is a means of explaining what structures perform what basic functions in the political system. It is a tool of investigation and based on certain basic assumptions and postulates. First, it takes the society as a single, interconnected system, each element of which performs a specific function. The basic feature of such system is the interactions of its components for the maintenance of its equilibrium. Second, if a society is a system as a whole, it has its parts that are interrelated. Lastly, underlying the whole social structure, there are broad aims and principles that are observed in members of the society (Fadia and Fadia, 2009:70). Ideology drives politics and politics drives the society, a defect in the ideology affects political actions of actors in these institutions. Just like catalyst speeds up the rate of chemical reaction in the natural sciences, ideology speeds up the rate of societal development or underdevelopment in the social sciences. Institutions are the needed machinery to drive home development. Development that is sustainable can be captured by the formular below:

$$
\text { D. } \Rightarrow \mathrm{f} \text { (I.P.I) } \quad \mathrm{D}=\text { Development, } \mathrm{F}=\text { Function, } \mathrm{I}=\text { = Ideology, } \mathrm{P}=\text { = Politics and I = Institutions }
$$

Sustainable development is a function of ideology, politics and institution. Ideology that is creative, politics that allocates resources in a prudent manner and institution that are strong and very viable to interpret the will and implement the policies of the state.

\subsection{Roots of Corrosive Politics}

In many political discuss, we have always heard people say that African leaders do not have ideology, even in the academia. Some speak like the journalist who tells you that Nigerian leaders do not have ideology, this in the first place is an error. What is ideology? Earliest political thinkers like Marx, Hegel, Keynes etc. had an idea of what they want their society to be then and in the future. Ideologies is different from values and attitudes but it is what gives room for values and attitudes that shape the society. According to (Johari (2011:202) ideologies are not the same as values and attitudes of the political culture. They are programmes for action and instruments of evaluation. They are a response to and a means of defending or changing existing political systems; they provide a language to conduct an examination of the political process. To Mosca, ideology is a political formular to solve political problems (see Dahl and Stinebuckner, 2003). In contemporary literature, the term ideology is applied to the set of ideas which are adopted by a group in order to motivate it for the achievement of a predetermined goals (Gauba, 2003:16). 
Socialism, capitalism, mixed economy, constructivist, federalists, democracy, terrorism, these are all offshoot of ideology, etc. The concept of primitive accumulation of wealth, corruption, individualism, etc. are all offshoot of ideology, ideology is either good or bad, constructive or destructive, leftist or rightist. The early nationalist leaders who pushed for our independence are not those who eventually led the nation. The first republic was characterized by corruption and gross embezzlement of public fund. When the military struck in 1966, there was a paradigm shift from the status quo, what they promised was not what they eventually did. They entrenched a new political system, which was eventually imbibed by the subsequent civilian regime to date. Ebohon calls it praetorian democracy, when he said that:

Praetorian democracy is essentially a post-military order navigated with civil command; driven by authoritarian culture and psychology. Unlike the organizational and praetorian absolutist models, it recognizes the need for accommodation of democratic structures even in their distorted forms. Similarly, it seeks to accommodate a larger gamut of the social forces and sectors of society without altering the command culture inherent in the praetorian absolutist order. In a sense, it recognizes the constitution and the democratic structures and institutions of state without recognizing the rule of law that flow from the constitution and the democratic structures and institutions of state without recognizing the rule of law that flow from the constitution and those democratic structures (Ebohon, 2009:31).

\subsection{The Role of Politics and Institutions in National Development}

Aristotle called politics the master science, i.e. almost everything happens in a political context. The decisions to allocate resource to different sectors of the economy is guided by politics. The budgetary allocation to the different sector is guided by politics, whether government should act or not to act is guided by politics and on whose interest. Some persons may tell you that economies are the master science, politics is guided by interest.

Robbins defined economies as a social science, which deals with the study of human behaviour as a relationship between ends and scarce means which have alternative uses (Jhingan, 2007:8). In the society there are competing demands at various sector either at the micro level (individuals) or the macro level (government) and the resources to meet them are limited (scarce) that is why there is scale of preference (order of priority) that is most needed to meet the needs of the society.

At the governmental level, where politics is needed to allocate resources for sustainable development, there are lots of pitfalls or shortcomings. It is the government that tells the banks to reduce taxes on loans or increase interest on loans depending on the goals of the government. It is government that decides to either constructs roads to link the rural areas with the urban centre for easy accessibility and economic development.

There is a linkage between politics and institutions in national development. institution are the vehicles which implement the will and policies of a state, they could either be economic, political, social and bureaucratic institutions. Institutions are as strong as the people who govern those institutions. What defines an institution or what makes an institution strong is the value preferences of the individuals and how well the rules and regulation governing that institutions are adhered to (Ohiorenuan and Osazuwa, 2016:5). Politicians are placed in these institutions, the vast natural resource capital and human resource capital are extracted by institutions and allocated by institutions, if there is a defect in these institutions invariably there will be a problem in the output or outcome.

\subsection{The Problematic in Nigerias Developmental Process}

When Nigeria gained her political independence from Britain, there were adequate linkage between the rural and urban centres, because the British needed to expropriated wealth back to their country, they made everything possible to ensure free flow of goods and services, but 57 years down the line the reverse is the case. The emergence of indigenous leaders brought in a new ideology and political mind set which has become individualistic and inimical to Nigerian's developmental process, a new political culture emerged and it has now been entrenched in our political system. There is a disarticulation of the national economy.

Experts believe the nation's economic managers should accept responsibility for not initiating real policies to vigorously diversity the economy with the advent of oil boom. As a result, there is what, the economist call "disarticulation" in the economy, meaning that there are no sufficient linkages between the oil and gas sector and the rest of the economy between the finance sector and small businesses between consumption and production and between industries and agricultural sector. Blessed with rich natural endowments and a teeming population of about 170 million people, Nigeria is widely acknowledged to have a great potential for development (Mordi, 2010:57).

The institutions to create these linkages are weak and the needed change becomes a tall task. Macintyre puts it thus: in broad terms, there are two sets of problems that must be overcome if the basic political rules of a state are to be reformed: difficulties of dislodging the existing institutional framework and difficulties of establishing a new framework. Difficulty of dislodging can arise because the defenders of the existing institutional framework resist fiercely or because the existing framework was designed in a way that makes it stubbornly temper-proof long after its defenders have declined or disappeared. Difficulties in establishing a new institutional framework can arise because of a protracted struggle to achieve a new dominant consensus or because of the laws in the design of the new framework has proved to be dysfunctional that it quickly collapses (Macintyre 2003:106).

Corrosive politics has encroached into the economic, political, bureaucratic and social institutions, it is expected that the rules of engagement and disengagement are adhered to in the public bureaucracy, it is expected that public 
procurement follows due process, it is expected that mode of extraction and distribution of resources follows due process, but today in Nigeria it is not so. As Ohiorenuan (2016:14) puts it thus:

In Nigeria today, you cannot tell where politics end and bureaucratic functions starts or where bureaucratic functions ends and politics start. The political executives have become politically bureaucratic in the performance of state functions.

\section{Effects of Dislocated Development}

\subsection{Neglect and Misuse of Natural Resource Capital}

Capital is a utility or wealth set aside, for further production of wealth or other utilities. Prior to the advent of the colonial masters Nigeria was well endowed with natural resource at each of the regions. In fact, this was the lure of the white men that made them come to Africa for raw materials for the development of their home industries. When the colonial masters left the stage and with the discovery of crude oil, the base of our common development was destroyed. Crude oil would have been an added advantage to our developmental process. After years of neglect the outcome is the importation of those resources that ordinarily we would have developed the capacity to produce for our consumption and export. Petroleum industry was subjected to corruption and rent-seeking development.

\subsection{Lack of Human Resource Capital Development and Utilization}

Human capital represents the human factor in the organization, the combined intelligence, skills and expertise that gives the organization its distinctive character. The human elements of the organization are those that are capable of learning, changing, innovating and providing the creative thrust which if properly motivated can ensure the long-term survival of the organization (Bontis, Dragonetti, Jacobsen, and Roos, 1999:391-402) in (Amstrong, 2006:33).

Human resource provides the behavioural aspect of the institutions or organization. The implementation of policies and programme is performed by the human resources in the institutions. For example, when oil was discovered, there was shortage of skilled man power hence the Obasanjo administration introduced the petroleum training and development fund (PTDF) to train persons to handle the petroleum industry, but today we still rely on foreign nationals to explore our crude oil for us.

\subsection{Disconnect Between the Rural and Urban Areas}

The rural areas have been the bedrock of most developing nations of Asia and Latin America, because these are the areas that produce the food and products for their industries. Even in Nigeria, we used to have farm settlement schemes, where youths are employed to work in the farms because they have conducive atmosphere just like you have on the urban centres. But with the neglect of agriculture and concentration on the petro-dollar, the rural centres has become a shadow of its former self, everybody wants to migrate to the urban centre thereby causing over-population, unemployment and food insecurity.

\subsection{Unemployment}

This is one of the problematics in Nigeria development process. When Nigeria's population began to increase, there was no adequate provision for employment structures. Arthur Lewis came up with the dual or two sector economy model, when he postulated the systematic theory of economic development with unlimited supply of labour see (Jhingan, 2011). The excess or surplus labour from the subsistence agricultural sector to the capitalist industrialized sector instead of the development planners to industrialized the nation and shift the excess manpower to the industrialized sector, the over-bloated the bureaucracy thereby increasing the recurrent expenditure and causing structural unemployment.

\subsection{Poverty}

Poverty is the inability to meet the basic needs of life, thereby subjecting individuals to installment death. Aristotle, once said "man is born free but everywhere in chains". This is a truism in the politics and development of the Nigeria state. The policies and programmes of the government more often than not are anti-people and anti-development. There is a difference between policy output and policy impact; the policies of the various administration have had minimal impact on the lives of the people. More than 70 percent of Nigerian live below 1 dollar per day about 60 percent of Nigerians is unemployed.

\section{Conclusion}

Corrosive politics guided by primitive and individualistic ideology has plunged Nigeria into this present state of underdeveloped and dislocated economy. Politics has encroached into the bureaucratic institutions and it has destroyed the fabrics of bureaucratic tenets, corrosive politics has also destroyed the economic base of the nation, despite the abundant natural resources capital and human capital. The existing framework created by corrosive politics has become difficult to be dislodged by any new framework and this as a result of the constructed society by the political actors who wants the status quo to remain as long as they benefit from it, it has become problematic to entrench a new institutional structure, even when economic reality demands it.

There is a delinkage between the rural and urban centres, there is a delinkage between agriculture and industry; politics when played with the mindset of development, modernization, happiness of the greatest number without denying the rights of the minority; when played within an altruistic scope will create the needed development. 


\section{Recommendations}

For Nigeria to have an articulated economy that will foster a holistic development, the following recommendations will suffice:

- The electoral process should be strengthened so that the people can have a say on who leads them, so that the leaders can be held accountable for their stewardship. If the electorates are not satisfied they can vote the leader out in the next election, just like you have in some more developed democracies.

- There should be a linkage between production and consumption. Most products that Nigeria imports today, are the things that we produced some years back. It has a negative effect on our balance of payment and balance of trade.

- There should be a linkage between the rural and urban centres by way of infrastructural development so that goods produced in the rural centres can be transported to the urban centres.

- Mechanised farming should be encouraged so that food for local consumption and export can be produced in a large scale and more efficient manner.

- There should be linkage between structures that perform similar and related functions, that helps for sustainable development. For example, linkage between agriculture and industries, between human resource capital and efficient bureaucracy etc.

- Those aspiring for political offices should have a picture of the kind of country or society that may want to create (ideology) that will foster development and not underdevelopment.

- This present administration should have the political will that drive home development.

\section{References}

i. Adamolekun, L. (1986). Politics and administration in Nigeria. Ibadan: Spectrum Books Ltd.

ii. Chapman, B. (1959). The profession of government. London: Allen and Unwin.

iii. Dahl, R.A. and Stinebrickner, (2010). Modern political analysis. New Delhi: Phi learning Private Limited.

iv. Ebohon, S.I. (2009). "Post-militarism: Provenance of praetorian democracy in Nigeria, 1999-2007". Journal of Social Sciences. 8(2): 129-138.

v. Gauba, O.P. (2003). An introduction to political theory. New Delhi: Macmillan India Ltd.

vi. Jhingan, M.L. (2007). Micro-economic theory. India: Vrinda Publications Ltd.

vii. Jhingan, M.L. (2011). The economics of development and planning. New Delhi: Vrinda Publications Ltd.

viii. Johari, J.C. (2011). Comparative politics. New Delhi: Sterling Publishers Private Limited.

ix. Kesselman, M., Kriegar, J. and Joseph, W.A. (2010). Introduction to comparative politics. Boston: Wadsworth.

x. Knox, R., Agnew, J. and McCarthy, L. (2008). The geography of the world economy. Britain: Hodder Education.

xi. Macintyre, A. (2003). The power of institutions: Political architecture and governance. New York: Cornell University Press.

xii. Ohiorenuan, E.C. (2016). Bureaucratic corruption and public service deficiency in Nigeria's Public Administration: The Way Forward. Paper presented at the University of Ilorin on the occasion of the first International Conference on Democracy and New Public Management: Emerging Issues and Challenges in Africa. 16-17, November.

xiii. Ohiorenuan, E.C. and Osazuwa, A.J. (2016). "Corruption and its challenges to national development: The Nigerian experience". Nigerian Journal of Administrative Science. 12(1): 1-14.

xiv. Otoghile, A. (2009). "Re-visiting a definition of politics: Problems and perspectives". Journal of Globalization and Development in Africa. 2(2):77-87.

xv. Reus-Smit, C. (2005). Constructivism in Scot Burchill, Andrew Linklater, Richard Devetak, Jack Donnelly, Matthew Paterson, Christian Reus-Smit and Jacqui True. Theories of International Relations. New York: Palgrave Macmillan.

xvi. Sodaro, M.J. (2008). Comparative Politics: A global introduction. New York: McGraw-Hill. 